Research Article

\title{
Spectroscopic Characterization of Eoholocene Bones Found in a Cave in Northeast Brazil
}

\author{
P. V. Oliveira, ${ }^{1}$ M. S. S. Viana, ${ }^{2}$ O. A. Barros, ${ }^{3}$ P. T. C. Freire, ${ }^{4}$ F. I. Bezerra, ${ }^{3}$ S. B. S. Gusmão, ${ }^{5}$ \\ B. C. Viana iD, ${ }^{5,6}$ and J. H. Silva iD ${ }^{7}$ \\ ${ }^{1}$ Universidade Federal do Piauí, Campus Senador Helvídio Nunes de Barros, 64607-670 Picos, PI, Brazil \\ ${ }^{2}$ Universidade Estadual Vale do Acaraú (UVA), 62010-290 Sobral, CE, Brazil \\ ${ }^{3}$ Pós-Graduação em Geologia (PPGG), Universidade Federal do Ceará (UFC), 60455-760 Fortaleza, CE, Brazil \\ ${ }^{4}$ Departamento de Física, Universidade Federal do Ceará, 60455-970 Fortaleza, CE, Brazil \\ ${ }^{5}$ Pós Graduação em Ciências e Engenharia dos Materiais (LIMAV), Universidade Federal do Piauí, $64049-550$ Teresina, \\ PI, Brazil \\ ${ }^{6}$ Departamento de Física, Universidade Federal do Piauí, 64049-550 Teresina, PI, Brazil \\ ${ }^{7}$ Centro de Ciências e Tecnologia-CCT, Universidade Federal do Cariri, 63048-080 Juazeiro do Norte, CE, Brazil
}

Correspondence should be addressed to B. C. Viana; bartolomeu@ufpi.edu.br and J. H. Silva; herminio@fisica.ufc.br

Received 21 May 2018; Revised 21 August 2018; Accepted 28 August 2018; Published 3 October 2018

Academic Editor: Vincenza Crupi

Copyright (C) 2018 P. V. Oliveira et al. This is an open access article distributed under the Creative Commons Attribution License, which permits unrestricted use, distribution, and reproduction in any medium, provided the original work is properly cited.

\begin{abstract}
The preservation of fossils depends on several interactions of organic and inorganic chemical processes. The hard parts, which are more suitable for fossilization, might record valuable information of biogenic processes, while the taphonomic characteristics supply information on postmortem chemical transformation. Here, X-ray fluorescence, X-ray diffraction, and infrared spectroscopy analyses were carried out in Early Eoholocene fragments of bones collected from the subsurface at Gruta do Urso Fóssil, Ubajara National Park, northeast of Ceará State in Brazil. It is suggested a lower degree of decomposition, a preservation of the original mineral composition, along with some incidence of encrustation, and the occurrence of different animal species are analyzed. These preliminary data serve as a basis for future studies involving fossil biota from the deposits of Gruta do Urso Fóssil using spectroscopic techniques.
\end{abstract}

\section{Introduction}

The hard parts (skeletons) which usually undergo fossilization keep valuable information of biogenic processes, and the taphonomic characteristics supply data on the postmortem changes [1]. Geochemical investigations and physical characterizations were performed to determine the composition of a fossil provide both taphonomic and ecologic data. Mineralogical composition of fossils can be adequately studied using physicochemical and mineralogical techniques such as X-ray fluorescence, X-ray diffraction, and infrared spectroscopy [2-4].

In northeastern Brazil, there are very important cenozoic continental deposits (especially caves) showing remains of organisms, valuable in the reconstruction of the paleoenviroment. The Ubajara National Park, in northeast Ceará State (Figure 1), is a karstic region where rocks suffered corrosion processes, subsequently creating caves and valleys. This region is part of a Spelean province composed by Neoproterozoic carbonatic rocks known as Serra da Ibiapaba, originating in the Upper NeogeneQuaternary according to Auler et al. [5, 6].

Of the 14 caves of the park, the most important is the Gruta do Urso Fóssil (GUF) which lies at $03^{\circ} 49^{\prime} 58^{\prime \prime} \mathrm{S} /$ $40^{\circ} 53^{\prime} 34,4^{\prime \prime} \mathrm{W}$. The GUF was discovered in 1978 in Morro do Pendurado, and a fossilized skull of Arctotherium wingei was found [7]. At GUF, several Early Eoholocene fragments of bones and teeth from small fauna, as well as gastropod shells, have been collected and reported in the specialized literature by Hsiou et al. [8], Oliveira et al. [9-11], and Viana [1]. 


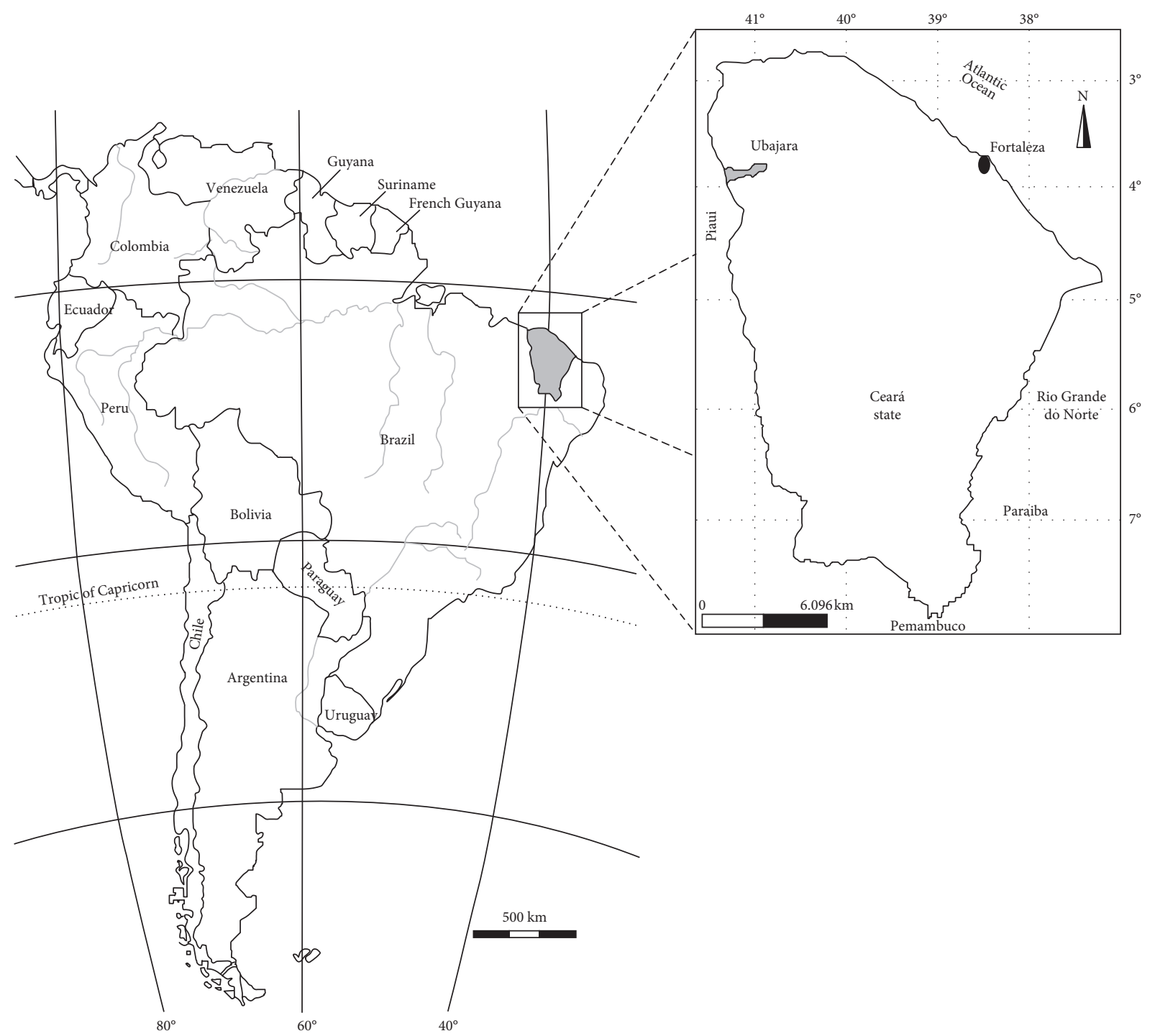

Figure 1: Map of South America, showing the Ceará state and the Ubajara town. Modified from Oliveira et al. [9].

Additionally, these authors assigned an approximate age of 8,000 years BP based on the thermoluminescence measurements of local sediments [9].

The main goal of this work is to present the qualitative, quantitative, and semiquantitative physicochemical composition of fossils from a cave in the Ubajara National Park (Ceará State), in order to obtain taphonomic information. Unidentified long bone fragments were selected and analyzed using X-ray fluorescence spectroscopy (XRF), X-ray diffraction (XRD), and infrared spectroscopy (IR).

\section{Materials and Methods}

This research was carried out in two stages: (1) the fieldwork for the stratigraphic analysis and collection of samples, and (2) the laboratory work to obtain data on the physicochemical and mineralogical composition of the samples, diagenetic transformation, and taphonomic analysis.
2.1. Fieldwork. A $90 \mathrm{~cm}$ deep excavation was carried out in the GUF's entrance chamber. A stratigraphic study was performed and divided into 8 layers of $10 \mathrm{~cm}$ depth, named from $\mathrm{C} 1$ to $\mathrm{C} 8$. The material of each layer was sieved in situ to collect mineralized organic samples, such as bones and teeth. In all, seven fragments of bones from the layers $\mathrm{C} 1$ to C6 and C8, were selected for X-ray diffraction, X-ray fluorescence, and infrared spectroscopy measurements. Due to the scarcity of bone samples, layer C7 was not analyzed.

2.2. Laboratorial Work. X-Ray diffraction is used to determine the atomic and molecular nature of a crystalline structure. X-ray fluorescence spectroscopy was used to analyse both major and trace chemical elements from a sample. Infrared spectroscopy was useful to identify chemical compounds and molecular compositions, including amorphous samples.

At the laboratory, the selected samples were crushed in a porcelain mortar with pestle for the following analysis. 
2.2.1. X-Ray Diffraction (XRD). The X-ray diffraction patterns were obtained using a Rigaku powder diffractometer with the Bragg-Brentano geometry. The $\mathrm{Co}-\mathrm{K} \alpha$ radiation was used and operated at $40 \mathrm{kV}$ and $25 \mathrm{~mA}$. The XRD measurements were taken in the $2 \theta$ range of $3-45^{\circ}$, using step scan procedures $\left(0.02^{\circ}\right)$ at counting times of $5 \mathrm{~s}$.

2.2.2. X-Ray Fluorescence Spectroscopy (XRF). The X-ray fluorescence spectroscopy was performed using a ZSX Mini II equipment from Rigaku, operating with a $\mathrm{Pb}$ tube, using a power of $40 \mathrm{kV} \times 1.2 \mathrm{~mA}$.

2.2.3. Infrared Spectroscopy. The infrared spectra were measured using the absorbance mode of transmittance measurement, and $\mathrm{KBr}$ pellets were used to dilute the samples. The samples were mixed with $\mathrm{KBr}$ powder in the proportion 1:100 from each sample (at about 5-10 mg). The pellet thickness varied from 0.5 to $0.6 \mathrm{~mm}$, and they were measured in the spectral range from 400 to $4000 \mathrm{~cm}^{-1}$ using a Vertex 70 spectrometer from Bruker.

\section{Results and Discussion}

The excavation resulted in the schematic section represented below, which demonstrates the stratigraphic distribution of the fossils in all layers found of unconsolidated sediments composed of both cave carbonate and siliciclastic material carried into the cave (Figure 2). The siliciclastic material was determined by microscopic analysis (not shown here), revealing the presence of small crystalline grains.

Table 1 summarizes the XRF analyses from seven small species of bone samples collected during the excavation at GUF. From this analysis, the main chemical elements were detected: $\mathrm{Ca}$ and $\mathrm{P}$, which are the mineral components of the bones, and trace elements such as $\mathrm{Zn}, \mathrm{Sr}, \mathrm{Si}, \mathrm{S}, \mathrm{Mn}, \mathrm{K}, \mathrm{Fe}, \mathrm{Cl}$, and $\mathrm{Al}$. The elements $\mathrm{K}, \mathrm{Si}, \mathrm{Al}, \mathrm{Fe}$, and $\mathrm{Cl}$ are basic constituents from the soil formation [12]. The amount of $\mathrm{Zn}$ in bones is an indicator of meat food, and the amount of Sr and $\mathrm{Mn}$ is an indicator of plant food, suggesting different species of animals were found [13]. Observing $\mathrm{Ca} / \mathrm{P}$ amount relationship, it is possible to infer about similar groups $\mathrm{C} 1, \mathrm{C} 3$, and C4 (9.3-8.2) and C5, C6, and C8 (6.2-5.5). However, C2 (7.6) can not be related with any group cited above.

The XRD diffractograms indexed hydroxyapatite $\left(\mathrm{Ca}_{10}(\mathrm{OH})_{2}\left(\mathrm{PO}_{4}\right)_{6}\right)$ as the majority phase in all samples, which were identified using the ICDD Reference code: 00001-1008, PDF index name: calcium hydroxide phosphate. These results suggest that the biomineralization of the bones is preserved (Figures 3 and 4). Other phases of the diffractograms include crystalline calcium carbonate as calcite $\left(\mathrm{CaCO}_{3}\right)$. The elemental analysis (XRF) was not able to identify $\mathrm{C}$ and $\mathrm{O}$ because of the limitation of equipment. However, $\mathrm{Ca}$ and $\mathrm{P}$ are the majority elements identified by $\mathrm{XRF}$, and the measurements are agreeing with XRD. These chemical characteristics and the incrustation observed from fossil analyses suggest that in all layers, there has been an

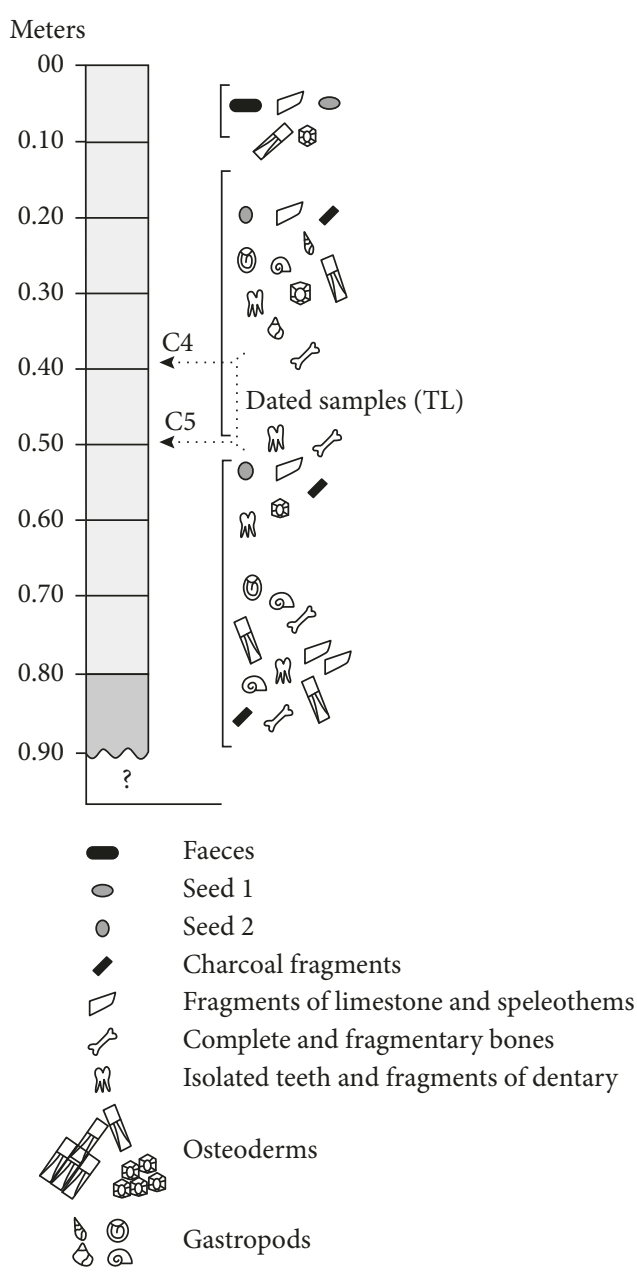

FIGURE 2: Schematic section showing the stratigraphic distribution of fossils in the GUF's entrance chamber [9].

TABle 1: Chemical elemental percentage of the C1, C2, C3, C4, C5, C6, and C8 samples measured by XRF.

\begin{tabular}{lccccccc}
\hline $\begin{array}{l}\text { Chemical } \\
\text { elements (\%) }\end{array}$ & C1 & C2 & C3 & C4 & C5 & C6 & C8 \\
\hline $\mathrm{Ca}$ & 69.45 & 82.20 & 86.67 & 83.80 & 82.03 & 83.17 & 82.13 \\
$\mathrm{P}$ & 8.39 & 10.76 & 9.33 & 10.00 & 13.34 & 13.56 & 14.82 \\
$\mathrm{Fe}$ & 0.43 & 0.35 & 0.00 & 0.54 & 0.68 & 0.35 & 0.27 \\
$\mathrm{~S}$ & 0.12 & 0.09 & 0.19 & 0.14 & 0.42 & 0.67 & 0.31 \\
$\mathrm{Al}$ & 0.15 & - & 0.09 & 0.17 & 0.59 & - & - \\
$\mathrm{Cl}$ & 0.48 & 0.27 & 0.44 & 0.24 & 0.13 & 0.26 & 0.45 \\
$\mathrm{~K}$ & 0.47 & 0.54 & 0.21 & 0.28 & 0.27 & 0.26 & 0.46 \\
$\mathrm{Mn}$ & - & 0.13 & - & 0.24 & 0.21 & - & 0.16 \\
$\mathrm{Si}$ & 0.36 & 0.46 & - & 0.62 & 1.93 & 1.30 & 1.01 \\
$\mathrm{Sr}$ & 2.31 & 4.58 & 2.34 & 2.24 & 0.19 & 0.18 & 0.18 \\
$\mathrm{Zn}$ & 0.49 & 0.21 & - & 0.41 & 0.10 & 0.12 & 0.10 \\
\hline
\end{tabular}

incrustation of calcium carbonate from the dissolution and reprecipitation of the cave's carbonatic rocks.

XRD diffractograms indexed the (002) plane related to the crystalline hydroxyapatite phase. The Debye-Scherrer equation (Equation (1)) was used to calculate the crystallite size [14] (Table 2): 


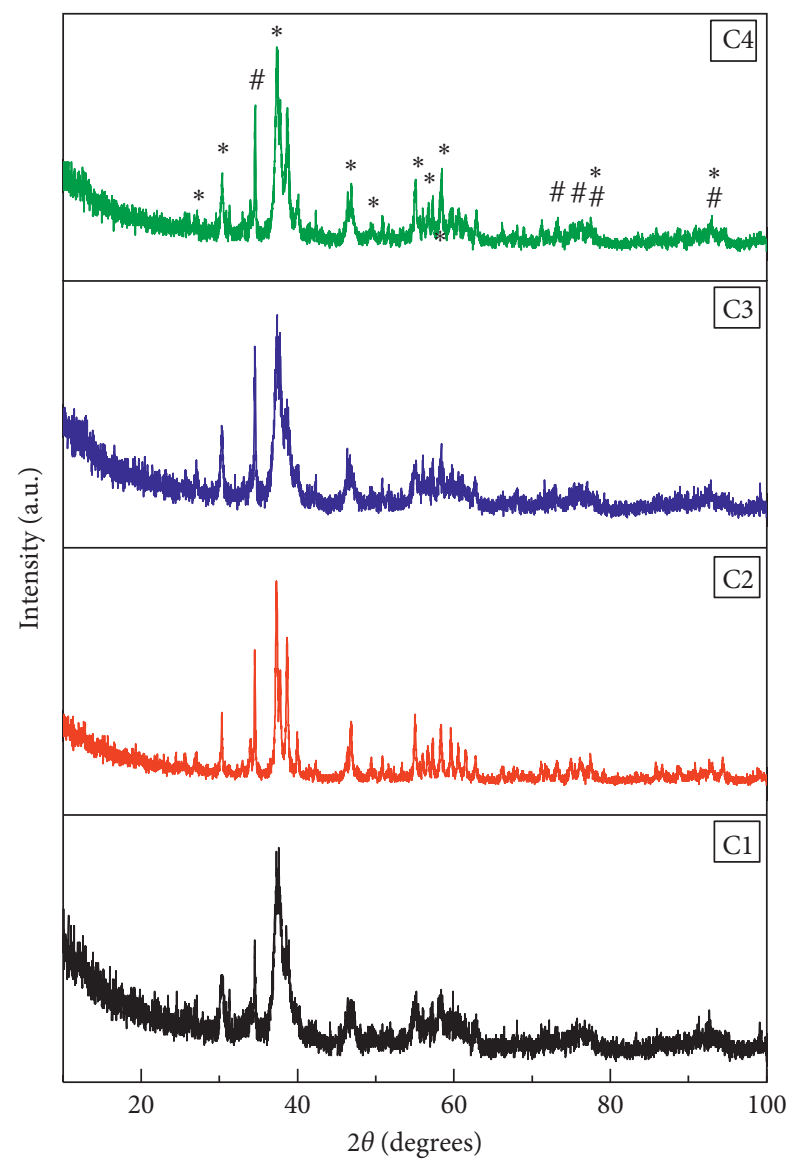

Figure 3: XRD diffractograms of the bone samples from the layers $\mathrm{C} 1, \mathrm{C} 2, \mathrm{C} 3$, and $\mathrm{C} 4$ analyzed, where peaks of hydroxyapatite $\left(^{*}\right)$ $\left(\mathrm{Ca}_{10}(\mathrm{OH})_{2}\left(\mathrm{PO}_{4}\right)_{6}\right)$ and calcite $(\#)\left(\mathrm{CaCO}_{3}\right)$ are assigned.

$$
\tau=\frac{k \lambda}{\beta \cos (\theta)},
$$

where $\tau$ is the size of crystallite (nm), $k$ is the shape constant, $k=0.9$, corresponding to the spherical shape, $\lambda$ is the Co-K $\alpha$ radiation wavelength $(1.7928 \AA), \beta$ is the full-width half maximum (FWHM) of the XRD peak plane (hkl), and $\theta$ is the diffraction angle (degrees) in accordance with Bragg's law and the (002) plane of crystalline hydroxyapatite $\left(\mathrm{Ca}_{10}(\mathrm{OH})_{2}\left(\mathrm{PO}_{4}\right)_{6}\right)$.

The results listed in Table 2 show that the sizes of crystallites were heterogeneous. Some groups presented similar crystallite sizes, C3 with C4, C2 with C5, and C6 with C8. The more crystalline samples showed larger crystallite sizes (C2 and C5).

The IR spectra (Figures 5 and 6) showed characteristic bands of hydroxyapatite [2-4]. Specifically, the bands centered at 467 and $557 \mathrm{~cm}^{-1}$ are associated with antisymmetric deformation of $\mathrm{PO}_{4}^{3-}$ ion, while the bands around $1020 \mathrm{~cm}^{-1}$ are related to the antisymmetric stretching of $\mathrm{PO}_{4}^{3-}$. Furthermore, calcite bands at $875 \mathrm{~cm}^{-1}$ correspond to symmetric deformations of $\mathrm{CO}_{3}^{2-}$, and bands at 1419 and $1460 \mathrm{~cm}^{-1}$ due to symmetric stretchings of $\mathrm{CO}_{3}^{2-}$ were observed [2-4]. IR results were synergistic with the XRF and
TABle 2: Size of the crystallite obtained in accordance with to the Scherrer equation, using the (002) diffraction plane of hydroxiapatite.

\begin{tabular}{lccc}
\hline Samples & $2 \theta\left(^{\circ}\right)$ Peak $(002)$ & $(2 \theta)$ FWHM & Crystallite size $(\mathrm{nm})$ \\
\hline C1 & 30.34 & 0.526 & 14 \\
C2 & 30.30 & 0.222 & 40 \\
C3 & 30.30 & 0.396 & 20 \\
C4 & 30.36 & 0.357 & 23 \\
C5 & 30.25 & 0.193 & 48 \\
C6 & 30.26 & 0.282 & 30 \\
C8 & 30.27 & 0.254 & 34 \\
\hline
\end{tabular}

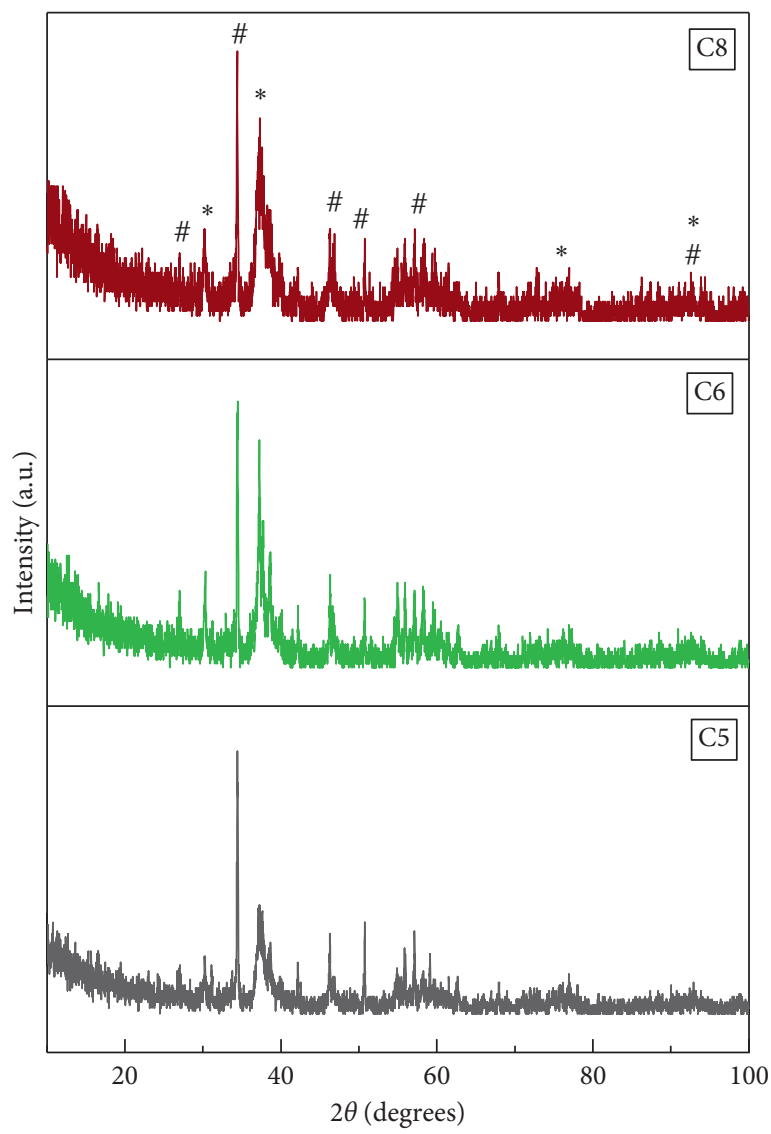

FIGURE 4: XRD diffractograms of bone samples analyzed. Results of the samples from the layers $\mathrm{C} 5, \mathrm{C} 6$, and $\mathrm{C} 8$, where peaks of hydroxyapatite $\left(^{*}\right)\left(\mathrm{Ca}_{10}(\mathrm{OH})_{2}\left(\mathrm{PO}_{4}\right)_{6}\right)$ and calcite $(\#)\left(\mathrm{CaCO}_{3}\right)$ are observed.

XRD analysis, suggesting together the presences of crystalline calcium, carbonate, and phosphate phases.

From the IR spectra, it is possible to estimate the relative amount of apatite and carbonate phases (Table 3 ). For this, the intensities of the two strongest peaks of both carbonate and phosphate phases were used. The base line was subtracted between $400 \mathrm{~cm}^{-1}$ and $1600 \mathrm{~cm}^{-1}$. The relative amount of carbonate/phosphate was calculated according to the following expression:

$$
\frac{\text { carbonate }}{\text { phosphate }}=\frac{A A^{\prime}+B B^{\prime}}{C C^{\prime}+D D^{\prime}},
$$




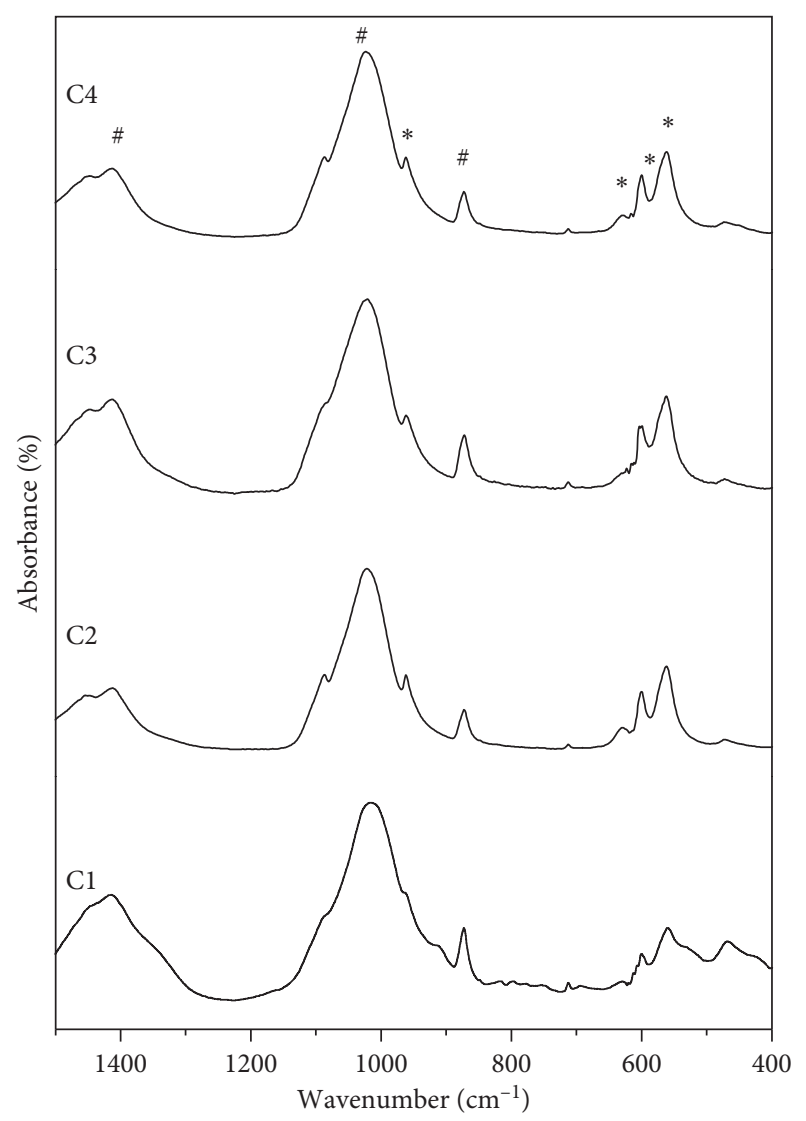

FIGURE 5: Infrared spectra of bone samples analyzed. Results of the samples from the layers $\mathrm{C} 1, \mathrm{C} 2, \mathrm{C} 3$, and $\mathrm{C} 4$, where peaks of hydroxyapatite $\left({ }^{*}\right)\left(\mathrm{Ca}_{10}(\mathrm{OH})_{2}\left(\mathrm{PO}_{4}\right)_{6}\right)$ and calcite $(\#)\left(\mathrm{CaCO}_{3}\right)$ are observed.

where $\left[A A^{\prime}+B B^{\prime}\right]$ is the intensity of the carbonite bands $\left(1447 \mathrm{~cm}^{-1}\right.$ and $1413 \mathrm{~cm}^{-1}$, respectively) and $\left[C C^{\prime}+D D^{\prime}\right]$ is the intensity of the phosphate bands $\left(599 \mathrm{~cm}^{-1}\right.$ and $561 \mathrm{~cm}^{-1}$, respectively).

The IR spectra also afforded the estimation of the amount of carbonate ions $(\% y)$ in the nanohydroxyapatite (nHAp) lattice (Table 3 ) by calculating the ratio of intensity between the carbonate at $1420 \mathrm{~cm}^{-1}\left(I_{\mathrm{c}}\right)$ and the phosphate at $598 \mathrm{~cm}^{-1}\left(I_{\mathrm{p}}\right)$ bands using the following equation [5]:

$$
\% y_{\mathrm{CO}_{3}}=10.134\left(\frac{I_{\mathrm{c}}}{I_{\mathrm{p}}}\right)+0.2134 \text {. }
$$

The use of XRD to address the crystallographic changes in ancient bones has often been documented [13-20]. The crystallinity Index $(\mathrm{CI})$ and carbonate/phosphate ratio $(\mathrm{C} / \mathrm{P})$ are extremely useful for the determination of the mineral alteration in both diagenetic and postdiagenetic bone. Here, we interpreted the CI as a representative of common diagenetic effects. Thus, we consider that the diagenesis in general sense, e.g., a decrease in histological preservation, increased with an increase in bone porosity and mineral crystallinity. Lee-Thorp and Sponheimer [21] discussed that the relationship between crystallinity and elemental alteration is not clear. Previous studies $[16,17]$ have suggested that an increase in CI values is not directly correlated with

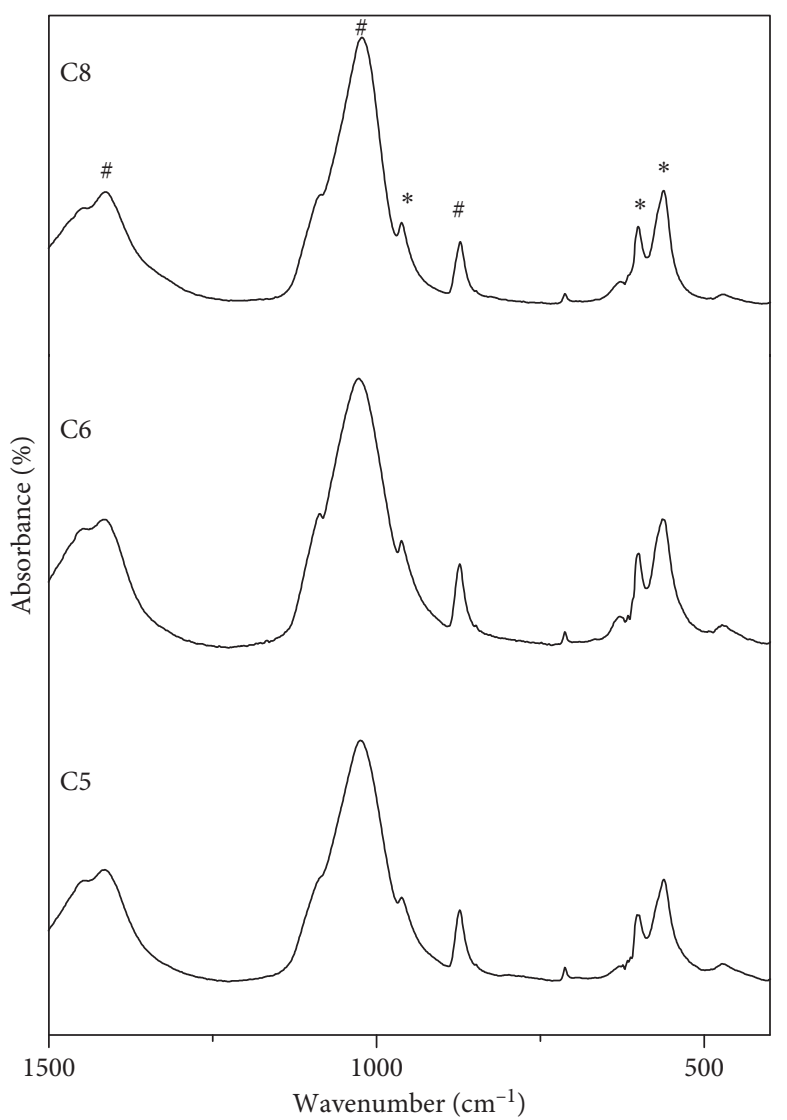

Figure 6: Infrared spectra of bone samples analyzed. Results of the samples from the layers $\mathrm{C} 5, \mathrm{C} 6$, and $\mathrm{C} 8$, where peaks of hydroxyapatite $\left(^{*}\right)\left(\mathrm{Ca}_{10}(\mathrm{OH})_{2}\left(\mathrm{PO}_{4}\right)_{6}\right)$ and calcite $(\#)\left(\mathrm{CaCO}_{3}\right)$ are observed.

TABLe 3: Average crystallinity index $\left(\mathrm{CI}_{\mathrm{X} \text {-ray }}\right)$ and relative carbonate/phosphate relative amount.

\begin{tabular}{lcc}
\hline Samples & $\mathrm{CI}_{\mathrm{X}-\text { ray }}$ (average) & Carbonate/phosphate (\%) \\
\hline C1 & 0.25 & 32.87 \\
C2 & 0.87 & 11.42 \\
C3 & 0.47 & 16.50 \\
C4 & 0.68 & 12.47 \\
C5 & 0.82 & 18.39 \\
C6 & 0.79 & 14.87 \\
C8 & 0.78 & 14.85 \\
\hline
\end{tabular}

the age of the bones, i.e., CI does not increase with increasing age. Furthermore, the CI range is not uniform between different chemical environments. Pucéat et al. [19], compared various CIs using Raman and FT-IR spectroscopy and X-ray diffractometry.

Early diagenetic factors (e.g., microbial attacks and hydrolysis) are associated with an increase of bone porosity $[22,23]$. According to Smith et al. [22], the increase of bone porosity can coincide with a decrease in CI values. The porosity may increase the interaction between bone and soil water, thereby causing a loss of organic content. Thus, exogenous minerals may be deposited within bone at any time postmortem. According to Table 3, the samples C2, C5, C6, 
and C8 present a small range of CI values. Although samples C3 and C6 exhibited slightly different values, the only significantly different value was that of $\mathrm{C} 1(0.25)$. The $\mathrm{C} 1$ sample results suggest the presence of calcite as an exogenous mineral, which is expected once the fossil is placed in a karst environment. In $\mathrm{C} 1$, there is a clear correlation between the increase of $\mathrm{C} / \mathrm{P}$ ratio with decreasing $\mathrm{CI}$ (Table 3). These results support the literature; for example, Astibia et al. [24] reported that the degree of crystallinity increased during fossilization.

The sample fossils from GUF are the same age; therefore, the most important parameter responsible for the observed range of $\mathrm{CI}$ and $\mathrm{C} / \mathrm{P}$ ratio values are local taphonomical conditions. The bone from $\mathrm{C} 1$ layer, at the top of the section, is most susceptible to interaction with pore-water and microorganisms accelerating the rate of dissolution, which facilitate exogenous and secondary minerals precipitation inside of the fossil. Indeed, the fact that the CI analyses do not differ significantly (barring sample C1) is not surprising because all samples come from the same locality. Therefore, this relative homogeneity can be explained by the fact that the remains have been deposited as individual bone fragments in the cave bottom. Person et al. [16] suggested that cave deposits offer the most favorable conditions for the preservation of original crystallinity. These facts suggest that the local conditions were key postdiagenesis parameters for the changes in the $\mathrm{CI}$ and $\mathrm{C} / \mathrm{P}$ ratio.

\section{Conclusions}

It has described here a bone assembly excavated from an Eoholocene deposit in northeast Brazil. The excavation at the GUF entrance cave allowed distinguishing eight layers composed of nonconsolidated sediments and very fossiliferous, especially with bones of small to medium size individuals, whose estimated age is approximately 8,200 years BP.

The biostratinomic characteristics observed in the field and in laboratory include the disarticulation and fragmentation of carcasses. The low concentrations of $\mathrm{Fe}$ and $\mathrm{S}$ indicated by the XRF analyses also demonstrated a very low degree of decomposition of the bones. The fossil diagenesis is represented by the following characteristics: (i) preservation of the biomineralization and (ii) a high incidence of incrustation (both analyzed by XRD and IR).

The Crystallinity and C/P ratio seem to be related to the local taphonomical conditions. The $\mathrm{C} 1$ sample clearly shows a correlation between the increase in $\mathrm{C} / \mathrm{P}$ ratio and the decrease of crystallinity indices; however, there are no great disparities among the other samples, which suggests that the bones remained in a closed system for long time, and it was not possible to confirm the number of different species.

\section{Data Availability}

The data used to support the findings of this study are available from the corresponding author upon request.

\section{Conflicts of Interest}

The authors declare that they have no conflicts of interest.

\section{Acknowledgments}

The authors are grateful to D. Lima (COOPTUR), G. C. Oliveira (UFPE), T. A. Lima (UVA), and A. D. A. Sousa (UFCE) for their support during fieldwork, and this work received support from CNPq (\#142942/2010-3) for Doctoral Fellowship (PVO). J. H. Silva acknowledges the support from the BPI-Notice no. 09/2015 and the CHAMADA UNIVERSAL MCTI/CNPq no. 014/2015. The authors would also like to thank Ms. Jessica Fitzgerald, Chemical Engineering Writing Consultant at Northeastern University, and Professor Anderson Lobo for providing English language corrections.

\section{References}

[1] M. S. S. Viana, C. L. Ximenes, L. A. S. Rocha, A. P. P. Chaves, and P. V. Oliveira, "Distribuição geográfica da megafauna pleistocênica no Nordeste brasileiro," in Paleontologia: Cenários de Vida, I. S. Carvalho, R. C. T. Cassab, C. Schwanke et al., Eds., pp. 797-809, Interciência Ed., Rio de Janeiro, RJ, Brazil, 2007.

[2] R. J. C. Lima, P. T. C. Freire, J. M. Sasaki, A. A. S. Saraiva, S. Lanfredi, and M. A. D. L. Nobre, "Estudo de coprólito da bacia sedimentar do Araripe por meios de espectroscopia FTIR e difração de Raios-X," Química Nova, vol. 30, no. 8, pp. 1956-1958, 2007.

[3] P. T. C. Freire, J. H. Silva, F. E. Sousa-Filho et al., "Vibrational spectroscopy and X-ray diffraction applied to the study of cretaceous fish fossils from araripe basin, Northeast of Brazil," Journal of Raman Spectroscopy, vol. 45, no. 11-12, pp. 12251229, 2014.

[4] F. E. Sousa Filho, J. H. da Silva, G. D. Saraiva et al., "Spectroscopic studies of the fish fossils (cladocyclus gardneri and vinctifer comptoni) from the Ipubi formation of the cretaceous period," Spectrochimica Acta Part A: Molecular and Biomolecular Spectroscopy, vol. 157, pp. 124-128, 2016.

[5] A. S. Auler, L. B. Piló, and A. Saadi, "Ambientes cársticos," in Quaternário do Brasil, C. R. G. Souza, K. Suguio, A. M. S. Oliveira, and P. E. Oliveira, Eds., pp. 321-342, Holos Ed., Ribeirão Preto, SP, Brazil, 2005.

[6] A. S. Auler, L. B. Piló, P. L. Smart et al., "U-series dating and taphonomy of quaternary vertebrates from brazilian caves," Palaeogeography, Palaeoclimatology, Palaeoecology, vol. 240, no. 3-4, pp. 508-522, 2006.

[7] L. H. Soibelzon, "Revision sistemática de los tremarctinae (Carnivora, Ursidae) fósiles de América del Sur," Revista del Museo Argentino de Ciencias Naturales, vol. 6, no. 1, pp. 107-133, 2004.

[8] A. S. Hsiou, P. V. Oliveira, C. L. Ximenes, and M. S. S. Viana, "Lizards and snakes (lepidosauria, squamata) from the late quaternary of the state of ceará in northeastern Brazil," Journal of Cave and Karst Studies, vol. 74, no. 3, pp. 262-270, 2012.

[9] P. V. Oliveira, M. S. S. Viana, and L. R. L. Simone, "Eoholocene malacofauna (Gastropoda, Pulmonata) from a cave of National Park of Ubajara," Estudos Geológicos, vol. 21, no. 1, pp. 85-93, 2011.

[10] P. V. Oliveira, A. M. Ribeiro, É. V. Oliveira, and M. S. S. Viana, "The dasypodidae (mammalia, xenarthra) from the urso fóssil 
cave (quaternary), parque nacional de ubajara, state of ceará, brazil: paleoecological and taxonomic aspects," Anais da Academia Brasileira de Ciências, vol. 86, no. 1, pp. 147-158, 2014.

[11] P. V. Oliveira, A. M. Ribeiro, M. S. S. Viana, and E. C. Holanda, "Tayassuidae, cervidae e tapiridae da gruta do urso fóssil, holoceno, parque nacional de ubajara, ceará, brasil," Revista Brasileira de Paleontologia, vol. 17, no. 3, pp. 417-434, 2014.

[12] P. G. Santos, J. A. Almeida, and L. Sequinatto, "Pedological heterogeneity of soils developed from lithologies of the pirambóia, sanga-do-cabral, and guará geological formations in southern Brazil," Revista Brasileira de Ciência do Solo, vol. 41, article e0160344, 2017.

[13] R. Allmäe, J. Limbo-Simovart, L. Heapost, and E. Verš, "The content of chemical elements in archaeological human bones as a source of nutrition research," Papers on Anthropology, vol. 21, pp. 27-49, 2012.

[14] S. Raynaud, E. Champion, D. Bernache-Assollant, and P. Thomas, "Calcium phosphate apatites with variable $\mathrm{Ca} / \mathrm{P}$ atomic ratio I. Synthesis, characterisation and thermal stability of powders," Biomaterials, vol. 23, no. 4, pp. 1065-1072, 2002.

[15] J. H. Silva, F. E. S. Filho, G. D. Saraiva et al., "Spectroscopic analysis of a theropod dinosaur (Reptilia, Archosauria) from the Ipubi formation, Araripe Basin, Northeastern Brazil," Journal of Spectroscopy, vol. 2013, 2013.

[16] A. Person, H. Bocherens, J. F. Saliège, F Paris, V. Zeitoun, and M. Gérard, "Early diagenetic evolution of bone phosphate: an X-ray diffractometry analysis," Journal of Archaeological Science, vol. 22, no. 2, pp. 211-221, 1995.

[17] J. Elorza, H. Astibia, X. Murelaga, and X. Pereda-Suberbiola, "Francolite as a diagenetic mineral in dinosaur and other upper cretaceous reptile bones (laño, iberian peninsula): microstructural, petrological and geochemical features," Cretaceous Research, vol. 20, no. 2, pp. 169-187, 1999.

[18] C. N. Trueman and N. Tuross, "Trace elements in recent and fossil bone apatite," Reviews in Mineralogy and Geochemistry, vol. 48, no. 1, pp. 489-521, 2002.

[19] E. Pucéat, B. Reynard, and C. Lécuyer, "Can crystallinity be used to determine the degree of chemical alteration of biogenic apatites?," Chemical Geology, vol. 205, no. 1-2, pp. 8397, 2004.

[20] B. Farre, P. Massard, J. Nouet, and Y. Dauphin, "Preservation of rodent bones from El Harhoura 2 cave (Morocco, neolithic-middle palaeolithic): microstructure, mineralogy, crystallinity and composition," Journal of African Earth Sciences, vol. 92, pp. 1-13, 2014.

[21] J. A. Lee-Thorp and M. Sponheimer, "Alteration of enamel carbonate environments during fossilization," Journal of Archaeological Science, vol. 26, pp. 143-150, 1999.

[22] C. I. Smith, C. M. Nielsen-Marsh, M. M. E. Jans, and M. J. Collins, "Bone diagenesis in the European holocene I: patterns and mechanisms," Journal of Archaeological Science, vol. 34, no. 9, pp. 1485-1493, 2007.

[23] M. M. E. Jans, C. M. Nielsen-Marsh, C. I. Smith, M. J. Collins, and H. Kars, "Characterisation of microbial attack on archaeological bone," Journal of Archaeological Science, vol. 31, pp. 87-95, 2004.

[24] H. Astibia, E. Buffetaut, A. D. Buscalioni et al., "The fossil vertebrates from lano (Basque Country, Spain); new evidence on the composition and affinities of the late cretaceous continental faunas of Europe," Terra Nova, vol. 2, no. 5, pp. 460-466, 1990. 

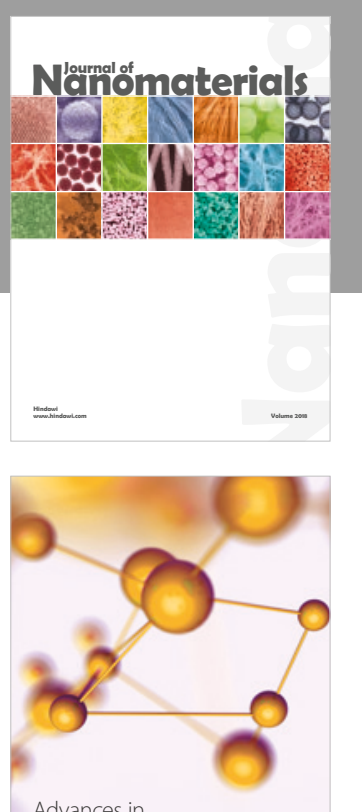

Physical Chemistry
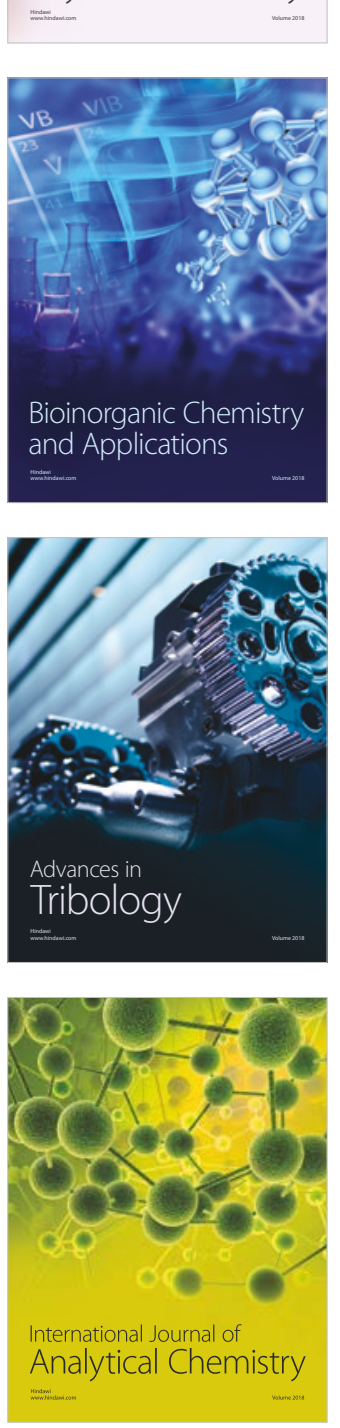

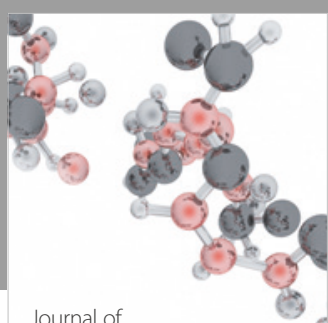

Analytical Methods

in Chemistry

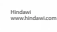

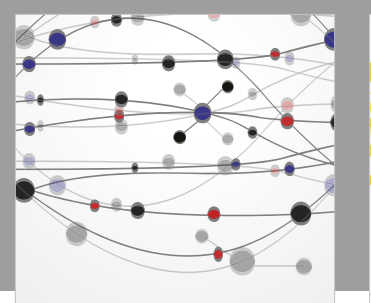

The Scientific World Journal

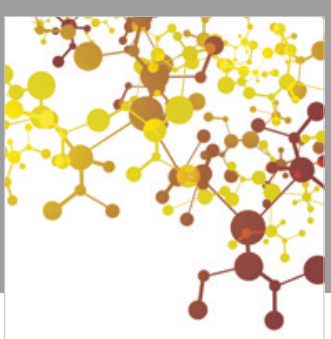

Journal of

Applied Chemistry
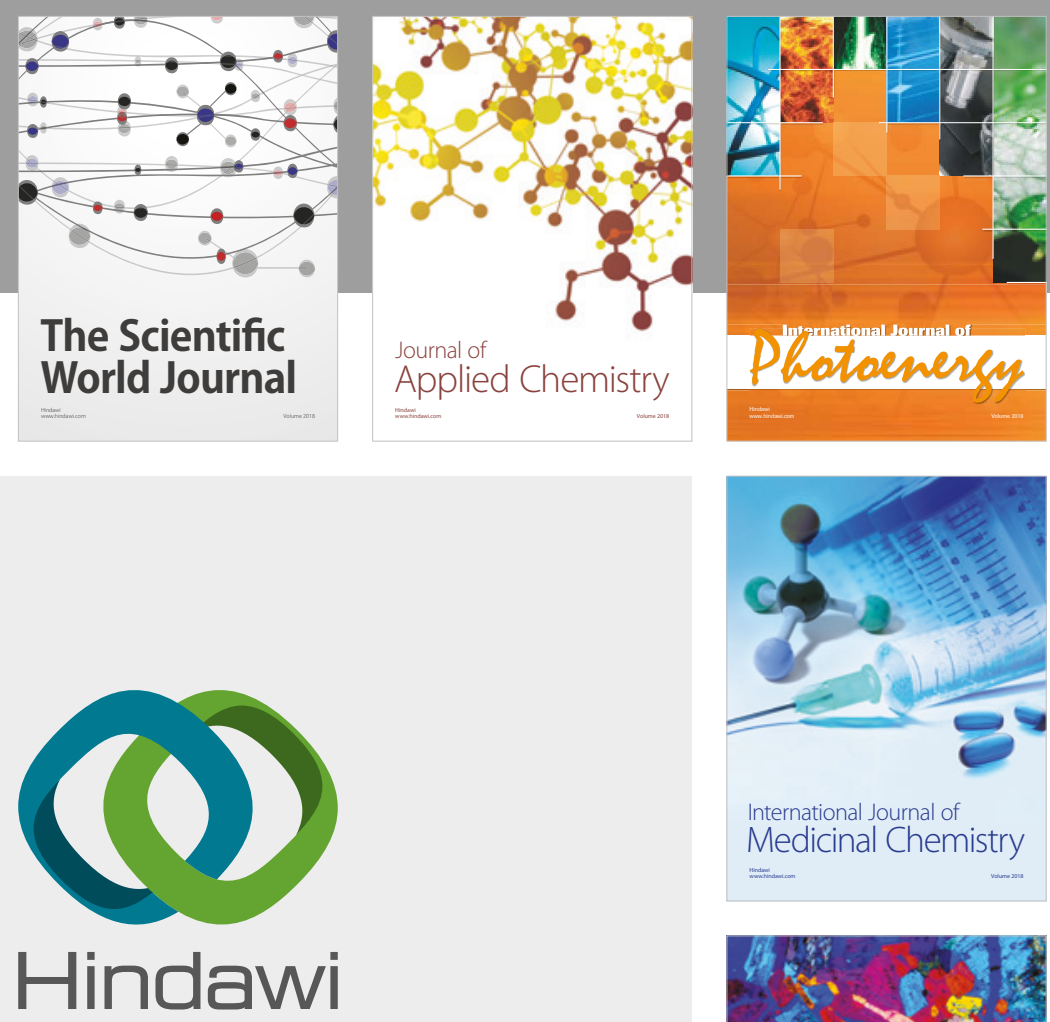

Submit your manuscripts at

www.hindawi.com
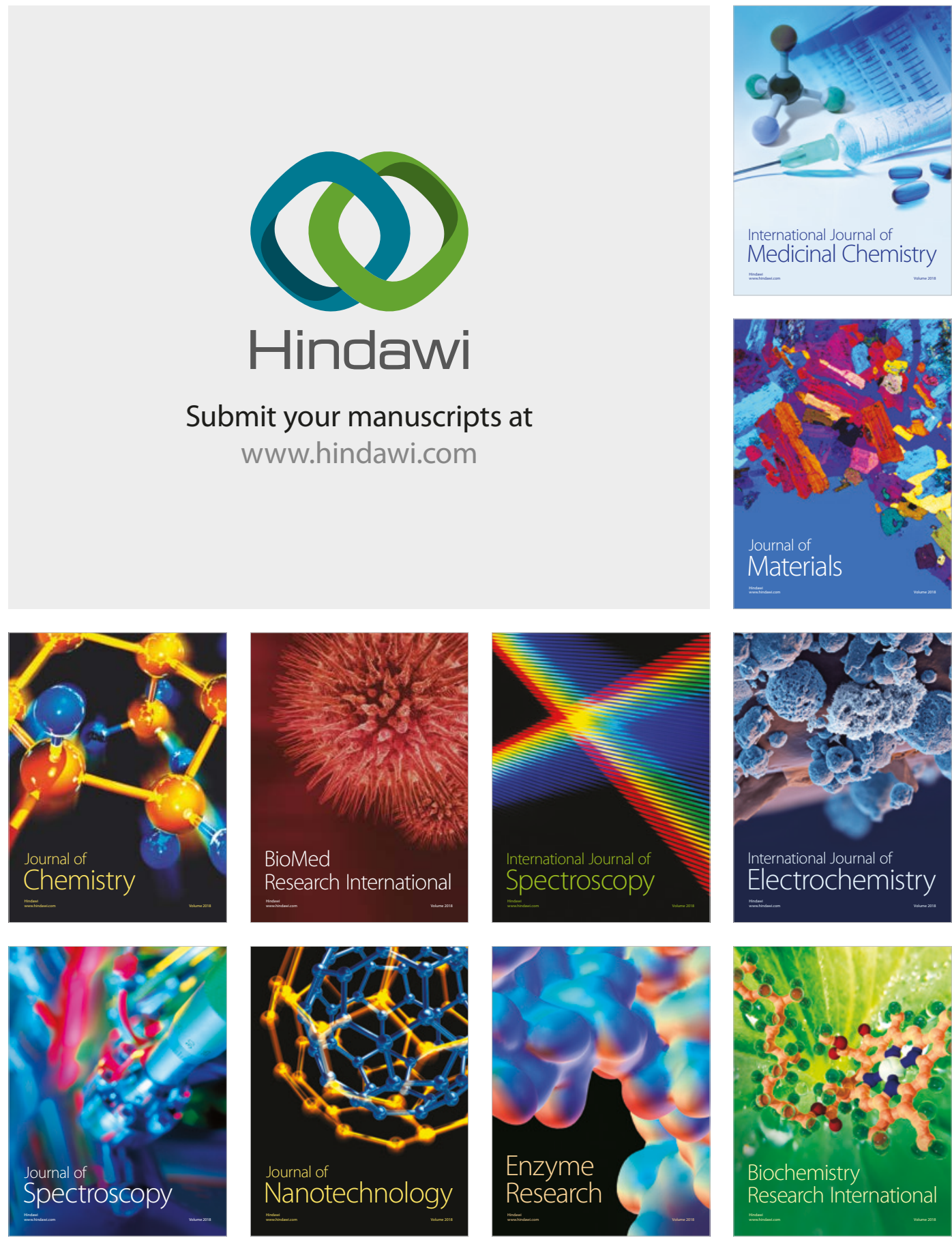
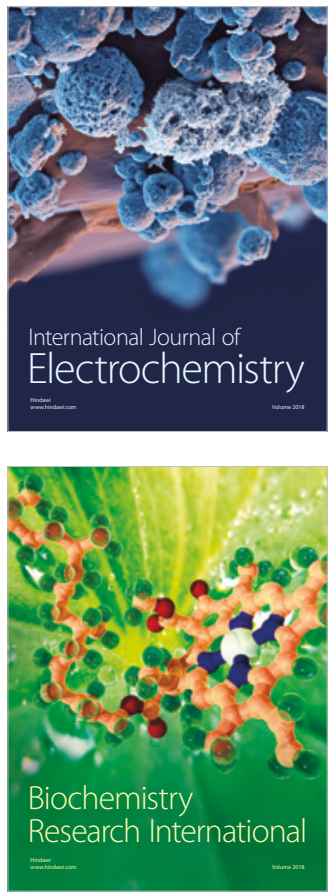